\title{
Association between WNT-1-inducible signaling pathway protein-1 (WISP1) genetic polymorphisms and the risk of gastric cancer in Guangxi Chinese
}

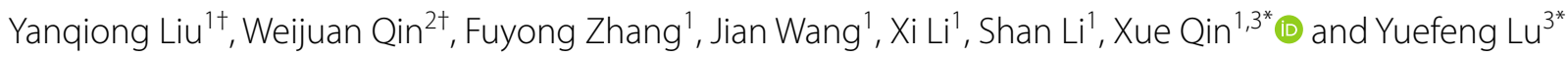

\begin{abstract}
Background: WNT1-inducible signaling pathway protein 1 (WISP1) is a member of the CCN protein family and a downstream target of $\beta$-catenin. Aberrant WISP1 expression may be involved in carcinogenesis. To date, no studies have investigated the association between single-nucleotide polymorphisms (SNPS) of WISP1 and gastric cancer. Therefore, we conducted this study to explore their relationship.
\end{abstract}

Methods: Polymerase chain reaction-restriction fragment length polymorphism assay was used to analyze three SNPs of WISP1 in 204 gastric cancer patients and 227 controls.

Results: Overall, we could not identify a significant association between WISP1 SNPs and gastric cancer risk. However, the subgroup analysis demonstrated that the presence of the rs7843546 T allele was associated with a significantly decreased risk of gastric cancer in those of Han Chinese ethnicity (CT vs. CC: OR $=0.33,95 \% \mathrm{Cl} 0.14-0.78$; TT vs. CC: $\mathrm{OR}=0.29,95 \% \mathrm{Cl} 0.11-0.76 ; \mathrm{CT}+\mathrm{TT}$ vs. $\mathrm{CC}: \mathrm{OR}=0.32,95 \% \mathrm{Cl} 0.14-0.74)$. In addition, patients with the rs7843546 TT genotype display a 0.34 -fold lower risk of developing stage I/II gastric cancer than those with the CC genotype Furthermore, individuals $\geq 50$ years old who carried the rs 10956697 AC genotype had a significantly decreased risk of gastric cancer $(\mathrm{OR}=0.58,95 \% \mathrm{Cl}$ 0.35-0.98). Smokers with the rs $10956697 \mathrm{AC}$ and $\mathrm{AC}+\mathrm{AA}$ genotypes exhibited a 0.28 -fold lower and 0.32-fold lower risk of gastric cancer, respectively.

Conclusions: The WISP1 SNPs rs7843546 and rs10956697 were, for the first time, found to reduce susceptibility to gastric cancer in various subgroups of Guangxi Chinese.

Keywords: WISP1, Polymorphism, Gastric cancer, Risk

*Correspondence: qinxue919@126.com; 2233795319@qq.com

${ }^{\dagger}$ Yanqiong Liu and Weijuan Qin equally contributed as first authors

${ }^{1}$ Department of Clinical Laboratory, The First Affiliated Hospital of Guangxi Medical University, Nanning, Guangxi, China

${ }^{3}$ Medical Equipment Department, The First Affiliated Hospital of Guangxi Medical University, Nanning, Guangxi, China

Full list of author information is available at the end of the article

\section{Background}

Globally, the burden of cancer incidence and mortality is rapidly growing. According to estimates from the World Health Organization (WHO), gastric cancer remains a commonly cancer worldwide and is responsible for $1,089,103$ new cases and an estimated 768,793 deaths in 2020, ranking fifth for incidence and fourth for mortality globally [1]. China is a high-incidence region in terms of gastric cancer. According to the 2020 global cancer statistics, 478,508 new gastric cancer cases and 373,789

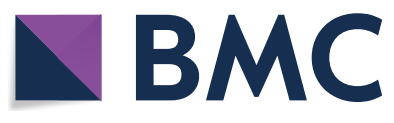

(C) The Author(s) 2021. Open Access This article is licensed under a Creative Commons Attribution 4.0 International License, which permits use, sharing, adaptation, distribution and reproduction in any medium or format, as long as you give appropriate credit to the original author(s) and the source, provide a link to the Creative Commons licence, and indicate if changes were made. The images or other third party material in this article are included in the article's Creative Commons licence, unless indicated otherwise in a credit line to the material. If material is not included in the article's Creative Commons licence and your intended use is not permitted by statutory regulation or exceeds the permitted use, you will need to obtain permission directly from the copyright holder. To view a copy of this licence, visit http://creativecommons.org/licenses/by/4.0/. The Creative Commons Public Domain Dedication waiver (http://creativeco mmons.org/publicdomain/zero/1.0/) applies to the data made available in this article, unless otherwise stated in a credit line to the data. 
deaths were estimated to have occurred in China in 2020, accounting for $43.9 \%$ and $48.6 \%$ of cases and deaths worldwide, respectively [2]. The high incidence and mortality in China highlight the importance of understanding the risk factors related to gastric cancer development. Also, gastric cancer has a multifactorial etiology in terms of risk factors, carcinogenesis, and epidemiologic patterns [3]. Chronic Helicobacter pylori infection is considered the primary cause, with almost all cases attributed to this bacterium [4]. The prevalence of $H$. pylori infection is extremely high, infecting half of the world's population [5]. However, only about $1 \%$ people with Helicobacter infections will develop gastric cancer, likely because of differences in host genetics, gender, age of infection acquisition, alcohol consumption, tobacco smoking, and environmental factors [6]. More novel and powerful methods of identifying the predisposing genetic factors are expected to provide new insights regarding the basic molecular pathways involved in tumorigenesis.

WNT1-inducible signaling pathway protein-1 (WISP1), also known as CCN4, is a cysteine-rich protein that belongs to the CCN protein family [7]. WISP1 is a target of the Wnt1 pathway, which can modulate multiple processes that involve tumorigenesis and stem cell proliferation [8]. WISP1 aberrant expression is associated with the promotion of various pathologies, including osteoarthritis, fibrosis, and cancer [9]. In 2017, Jia et al. first suggested that WISP1was up-regulated in gastric cancer and acted as an oncogene by promoting proliferation, migration, and invasion in gastric cancer cells [10]. Additionally, Zhang et al. demonstrated that significantly up-regulated WISP1 expression was associated with cancer progression, chemotherapy outcomes, and poor prognosis in gastric cancer in 2019 [11]. The observation that WISP1 plays an important role in the progression of gastric cancer highlights the importance of identifying the variants of this gene because a single nucleotide polymorphism (SNP) can change the encoded amino acids in a protein when it arises in the related coding sequence, thus influencing gene function and phenotype [12].

The WISP1 gene consists of five exons and four introns located on chromosome 8q24.1 to 8q24.3, and it has been shown to be highly polymorphic [13]. Several clinical studies have indicated a significant association between WISP1 polymorphisms and various cancers, such as breast cancer [14], urothelial cell carcinoma [15], hepatocellular carcinoma [16], oral squamous cell carcinoma [17], lung cancer [18] and uterine cervical cancer [19]. Up until now, to our knowledge, no study has established a connection between WISP1 genetic polymorphisms and gastric cancer. Therefore, we conducted this study to explore the association between the WISP1 SNPs rs2929973, rs7843546, and rs10956697 and susceptibility to gastric cancer in a Guangxi (Southwest China) population.

\section{Methods \\ Sample size consideration}

We estimated the sample size using Quanto software (Version 1.2.4) [20, 21]. An unmatched case-control design will be used. The prevalence of the WISP1 SNP rs2929973 $\mathrm{T}$ allele in the HapMap global population is 0.8451 (HapMap Project dbSNP database: http://www. ncbi.nlm.nih.gov/snp/). The inheritance model is recessive. The relative risk is 2.0 . The desired power is $80 \%$ at a significance level of 0.05 , with a two-sided alternate hypothesis. According to the above parameters, the estimated 186 case-control pairs required for the desired power to assess the risk of WISP1 genetic variation on gastric cancer development.

\section{Study subjects}

We enrolled 204 gastric cancer patients in this study. All cases were newly clinically and pathologically confirmed as primary gastric cancer without a history of abdominal surgery and admitted to the First Affiliated Hospital of Guangxi Medical University, Guangxi, China, as has been described in our previous study [22]. Patients were excluded if they had any of the following: (a) concomitant malignant neoplasia, (b) acquired immunodeficiency syndrome, (c) acute or chronic inflammatory diseases, and (d) positive antibodies for H. pylori.

For the control group, we selected 227 healthy individuals recruited from the general health check-up centers at the same hospital during the same period of the study. The individuals in the control group had no previous genetic history of the tumor and were matched with the case group in terms of gender and age. The clinical and pathological characteristics of all subjects were collected based on an electronic medical record system.

\section{Selection of WISP1 SNPs}

For this study, SNPs were selected based on data from the International HapMap Project (http://hapmap.ncbi. nlm.nih.gov/), dbSNP database (http://www.ncbi.nlm. nih.gov/projects/SNP/), and findings of previous studies reporting the effect of WISP1 genetic polymorphisms on cancer susceptibility $[14-19,23]$. All SNPs had minor allele frequencies (MAF) of $>5 \%$ to prevent false-negative results. Based on the aforementioned criteria, three SNPs were selected: rs2929973, rs7843546, and rs10956697.

\section{DNA extraction and WISP1 genotyping}

Genomic DNA was isolated from EDTA-anticoagulated venous blood using the phenol-chloroform protocol, as described in detail in our previous studies $[22,24]$. The 
concentration and purity of the DNA were determined spectrophotometrically. The obtained DNA was stored at $-20{ }^{\circ} \mathrm{C}$ and prepared for genotyping using polymerase chain reaction (PCR). Genotyping was conducted via restriction fragment length polymorphism (RFLP) assay, as described previously $[22,24]$.

\section{DNA sequencing}

To determine the accuracy of the polymerase chain reaction-restriction fragment length polymorphism (PCRRFLP) method, a random selection of $>5 \%$ of all samples was genotyped via the direct sequencing method with an ABI Prism 3100 (Applied Biosystems, Shanghai Sangon Biological Engineering Technology \& Services Co., Ltd., China). The resultant genotypes showed no differences.

\section{Statistical analysis}

A student's $T$-test or Mann-Whitney $U$ test was applied to analyze the continuous variables. The $x^{2}$ test or Fisher's exact test was applied to analyze the categorical variables. Adjusted odds ratios (AORs) and 95\% confidence intervals (CIs) were estimated using logistic regression models. These AORs and 95\%CIs were used to assess the association between genotype frequencies and gastric cancer risk and clinical and pathological characteristics. To evaluate the joint effects of the three SNPs in the WISP1 gene, SHEsis software (http://analysis.bio-x. cn/myAnalysis.php) [25] was employed to construct haplotypes between the patients and controls. SPSS Version 16.0 for Windows (SPSS Inc., IL, USA) software was used for all the statistical analyses. A two-sided P-value of $<0.05$ was accepted as statistically significant.

\section{Results}

\section{Characteristics of the study subjects}

Table 1 shows the demographic and clinical characteristics of all the subjects in the study. In total, 204 gastric cancer patients and 227 controls were enrolled in the study. Their ages and sexes were well-matched $(\mathrm{P}=0.057$ and $\mathrm{P}=0.954$, respectively). There were no differences between the two groups in terms of smoking, drinking alcohol, or ethnicity. The patient groups had a significantly lower average BMI as compared to the healthy controls. Most patients (70.6\%) had stage III/IV gastric cancer, while $29.4 \%$ had stage I/II disease. Most tumors $(82.4 \%)$ were classified as undifferentiated or poorly differentiated (Table 1).

\section{WISP1 polymorphisms and gastric cancer risk}

The genotypic distributions of the WISP1 SNPs rs2929973, rs7843546, and rs10956697 in the gastric cancer group and normal control group were all in accordance with the Hardy-Weinberg equilibrium $(\mathrm{P}>0.05)$.
Table 1 The distributions of demographical characteristics in 227 controls and 204 patients with gastric cancer

\begin{tabular}{|c|c|c|c|}
\hline Characteristics & Patients $(N=204)$ & Controls $(\mathrm{N}=227)$ & $P$ value \\
\hline $\begin{array}{l}\text { Ages(mean } \pm S D \text {, } \\
\text { years) }\end{array}$ & $54.31 \pm 12.00$ & $52.58 \pm 5.13$ & 0.057 \\
\hline $\begin{array}{l}\text { BMI (mean } \pm S D \text {, } \\
\mathrm{kg} / \mathrm{m}^{2} \text { ) }\end{array}$ & $20.59 \pm 3.11$ & $22.47 \pm 3.47$ & $<0.001^{*}$ \\
\hline \multicolumn{4}{|l|}{ Gender } \\
\hline Male & $134(65.7 \%)$ & $138(60.8 \%)$ & \multirow[t]{2}{*}{0.954} \\
\hline Female & $70(34.0 \%)$ & $89(39.2 \%)$ & \\
\hline \multicolumn{4}{|l|}{ Ethnicity } \\
\hline Han & $99(48.5 \%)$ & $112(49.3 \%)$ & \multirow[t]{3}{*}{0.975} \\
\hline Zhuang & $92(45.1 \%)$ & $100(44.1 \%)$ & \\
\hline Other & $13(6.4 \%)$ & $15(6.6 \%)$ & \\
\hline \multicolumn{4}{|l|}{ Smoking } \\
\hline Yes & $58(28.4 \%)$ & $71(31.3 \%)$ & \multirow[t]{2}{*}{0.519} \\
\hline No & $146(71.6 \%)$ & $156(68.7 \%)$ & \\
\hline \multicolumn{4}{|l|}{ Drinking alcohol } \\
\hline Yes & $52(25.5 \%)$ & $67(29.5 \%)$ & \multirow[t]{2}{*}{0.351} \\
\hline No & $152(74.5 \%)$ & $160(70.5 \%)$ & \\
\hline \multicolumn{4}{|l|}{ Cell differentiation } \\
\hline $\begin{array}{l}\text { Moderate and } \\
\text { poor }\end{array}$ & $168(82.4 \%)$ & & \\
\hline Well & $36(17.6 \%)$ & & \\
\hline \multicolumn{4}{|l|}{ Clinical stage } \\
\hline$|/| \mid$ & $60(29.4 \%)$ & & \\
\hline III/IV & $144(70.6 \%)$ & & \\
\hline \multicolumn{4}{|c|}{ Family history of gastric cancer } \\
\hline Yes & $6(2.9)$ & $4(1.8)$ & 0.833 \\
\hline No & $198(97.1)$ & $223(98.2)$ & \\
\hline
\end{tabular}

$S D$ standard deviation

${ }^{*} P$ value $<0.05$ as statistically significant

The frequency distribution and logistic regression analysis of the polymorphisms of the WISP1 gene in the gastric cancer and control groups are shown in Table 2. After logistic regression adjustment analysis based on gender, age, BMI, ethnicity, smoking, and drinking alcohol, no significant differences were observed between gastric cancer patients and the control group in terms of the rs2929973, rs7843546, and rs10956697 polymorphisms of the WISP1 gene.

To clarify the role of WISP1 genetic polymorphisms in gastric cancer's demographic and clinical variables, the respective SNPs were analyzed to determine their correlations with clinical parameters. Tables 3, 4, 5 and Additional files 1, 2, 3, 4 present the results of the subgroup analyses performed by clinical stage, cell differentiation, gender, age, ethnicity, smoking status, and drinking status. In an evaluation of clinical stage and rs7843546 WISP1 genotypes, patients with the TT genotype displayed a 0.34 -fold lower risk of developing stage 
Table 2 The frequency distribution and logistic regression analysis of the polymorphism of WISP1 gene in gastric cancer and control group

\begin{tabular}{lllll}
\hline Variables & $\begin{array}{l}\text { Gastric cancer } \\
(\mathrm{N}=204) \mathrm{n}(\%)\end{array}$ & $\begin{array}{l}\text { Controls } \\
(\mathrm{N}=227) \mathrm{n}\end{array}$ & AOR $(95 \% \mathrm{Cl})$ & $P$ \\
& & $(\%)$ & & \\
& & &
\end{tabular}

\begin{tabular}{|c|c|c|c|c|}
\hline \multicolumn{5}{|l|}{ rs2929973 } \\
\hline \multicolumn{5}{|l|}{ Alleles } \\
\hline $\mathrm{T}$ & $285(69.9)$ & $295(65.0)$ & $1.00^{\text {ref }}$ & \\
\hline G & $123(30.1)$ & $159(35.0)$ & $0.83(0.61-1.13)$ & 0.230 \\
\hline \multicolumn{5}{|c|}{ Co-dominant } \\
\hline $\mathrm{TT}$ & $100(49.0)$ & $102(44.9)$ & $1.00^{\text {ref }}$ & \\
\hline TG & $85(41.7)$ & $91(40.1)$ & $0.99(0.64-1.54)$ & 0.967 \\
\hline GG & $19(9.3)$ & $34(15.0)$ & $0.63(0.32-1.21)$ & 0.164 \\
\hline \multicolumn{5}{|l|}{ Dominant } \\
\hline $\mathrm{TT}$ & $100(49.0)$ & $102(44.9)$ & $1.00^{\text {ref }}$ & \\
\hline $\mathrm{TG}+\mathrm{GG}$ & $104(51.0)$ & $125(55.1)$ & $0.88(0.58-1.32)$ & 0.536 \\
\hline \multicolumn{5}{|l|}{ Recessive } \\
\hline $\mathrm{TT}+\mathrm{TG}$ & $185(90.7)$ & $193(85.0)$ & $1.00^{\text {ref }}$ & \\
\hline GG & $19(9.3)$ & $34(15.0)$ & $0.62(0.33-1.17)$ & 0.141 \\
\hline \multicolumn{5}{|l|}{ rs7843546 } \\
\hline \multicolumn{5}{|l|}{ Allele } \\
\hline C & $191(46.8)$ & $191(42.1)$ & $1.00^{\text {ref }}$ & \\
\hline T & $217(53.2)$ & $263(57.9)$ & $0.84(0.63-1.12)$ & 0.224 \\
\hline \multicolumn{5}{|c|}{ Co-dominant } \\
\hline $\mathrm{CC}$ & $41(20.1)$ & $36(15.9)$ & $1.00^{\text {ref }}$ & \\
\hline CT & $109(53.4)$ & $119(52.4)$ & $0.86(0.49-1.48)$ & 0.577 \\
\hline TT & $54(26.5)$ & $72(31.7)$ & $0.68(0.37-1.24)$ & 0.204 \\
\hline \multicolumn{5}{|l|}{ Dominant } \\
\hline CC & $41(20.1)$ & $36(15.9)$ & $1.00^{\text {ref }}$ & \\
\hline$C T+T T$ & $163(79.9)$ & $191(84.1)$ & $0.79(0.47-1.33)$ & 0.376 \\
\hline \multicolumn{5}{|l|}{ Recessive } \\
\hline $\mathrm{CT}+\mathrm{CC}$ & $150(73.5)$ & $155(68.3)$ & $1.00^{\text {ref }}$ & \\
\hline $\mathrm{TT}$ & $54(26.5)$ & $72(31.7)$ & $0.78(0.50-1.21)$ & 0.262 \\
\hline \multicolumn{5}{|l|}{ rs10956697 } \\
\hline \multicolumn{5}{|l|}{ Allele } \\
\hline C & $278(68.1)$ & $286(63.0)$ & $1.00^{\text {ref }}$ & \\
\hline A & $130(31.9)$ & $168(37.0)$ & $0.88(0.65-1.20)$ & 0.421 \\
\hline \multicolumn{5}{|c|}{ Co-dominant } \\
\hline CC & 95 (46.6) & $86(37.9)$ & $1.00^{\text {ref }}$ & \\
\hline$A C$ & $88(43.1)$ & $114(50.2)$ & $0.78(0.50-1.19)$ & 0.248 \\
\hline AA & $21(10.3)$ & 27 (11.9) & $0.90(0.45-1.79)$ & 0.771 \\
\hline \multicolumn{5}{|l|}{ Dominant } \\
\hline CC & 95 (46.6) & 86 (37.9) & $1.00^{\text {ref }}$ & \\
\hline$A C+A A$ & $109(53.4)$ & $141(62.1)$ & $0.79(0.52-1.19)$ & 0.254 \\
\hline \multicolumn{5}{|l|}{ Recessive } \\
\hline$C C+A C$ & $183(89.7)$ & $200(88.1)$ & $1.00^{\text {ref }}$ & \\
\hline AA & $21(10.3)$ & $27(11.9)$ & $1.02(0.53-1.96)$ & 0.947 \\
\hline
\end{tabular}

ref reference; $A O R$ Adjusted odds ratio; $95 \% \mathrm{Cl} 95 \%$ confidence interval; adjusted for age, BMl ethnicity, smoking and drinking alcohol
I/II gastric cancer than those with the CC genotype $(\mathrm{OR}=0.34 ; 95 \% \mathrm{CI} 0.14-0.84 ; \mathrm{P}=0.020)$ (Table 3) after adjusting for gender, age, BMI, ethnicity, smoking, and drinking. In addition, after adjustment for the abovementioned variables, subjects carrying at least one copy of the $\mathrm{T}$ allele for the rs7843546 SNP exhibited a 0.46fold lower risk of stage I/II gastric cancer than those with the $\mathrm{CC}$ genotype (dominant model: $\mathrm{CT}+\mathrm{TT}$ vs. $\mathrm{CC}$, $\mathrm{OR}=0.46,95 \%$ CI $0.22-0.96, \mathrm{P}=0.038$ ) (Table 3). However, the other SNPs genotypes did not exhibit a significant difference in this regard.

When the subjects were further divided into subgroups according to the age, significant differences were found in the genotypic distributions of the WISP1 SNP rs10956697 in subjects $\geq 50$ years old carrying the AC genotype as compared with those carrying the $\mathrm{CC}$ genotype (AC vs. $\mathrm{CC}: \mathrm{OR}=0.58,95 \% \mathrm{CI} 0.35-0.98, \mathrm{P}=0.043$ ) (Additional file 1). No difference was observed in subjects $<50$ years old.

As regards ethnicity, for the Han Chinese ethnicity, the presence of the rs7843546 $\mathrm{T}$ allele was associated with a significantly decreased risk of gastric cancer (CT vs. CC: $\mathrm{OR}=0.33,95 \% \mathrm{CI} 0.14-0.78, \mathrm{P}=0.012$; TT vs. CC: $\mathrm{OR}=0.29,95 \% \mathrm{CI} 0.11-0.76, \mathrm{P}=0.012$; dominant model $\mathrm{CT}+\mathrm{TT}$ vs. $\mathrm{CC}: \mathrm{OR}=0.32,95 \% \mathrm{CI} 0.14-0.74, \mathrm{P}=0.007$ ), whereas the association was not statistically significant among the Zhuang population cohort (Table 4).

In the smoking status cohort, compared with patients carrying the CC genotype of SNP rs10956697, those with the $\mathrm{AC}$ and $\mathrm{AC}+\mathrm{AA}$ genotype exhibited a 0.28fold lower risk and 0.32-fold lower risk of gastric cancer $(\mathrm{OR}=0.28,95 \%$ CI $0.09-0.82, \mathrm{P}=0.021$ and $\mathrm{OR}=0.32$, $95 \%$ CI $0.12-0.89, \mathrm{P}=0.030$, respectively) (Additional file 2). No difference was observed in the non-smoker cohort. No effect on the part of cell differentiation (Table 5), gender, or drinking status on the association between the WISP1 polymorphism and susceptibility to gastric cancer was observed. No significant association was observed between the WISP1 rs2929973 polymorphism and risk of gastric cancer in any genetic models.

\section{Discussion}

WISP1 polymorphisms have been identified in various cancers, including breast cancer [13], urothelial cell carcinoma [14], hepatocellular carcinoma [15], oral squamous cell carcinoma [16], lung cancer [17], and uterine cervical cancer [18], but data are scant as to the involvement of WISP1 polymorphisms in gastric cancer. As far as we are aware, our study is the first to investigate the distributions of the rs2929973, rs7843546, and rs10956697 SNPs and their associations with the development of gastric cancer in a Guangxi Chinese population. Our results revealed the correlations between WISP1 SNPs 
Table 3 Distribution frequency of WISP1 polymorphisms in controls and gastric cancer patients stratified by clinical stage

\begin{tabular}{|c|c|c|c|c|c|c|c|}
\hline \multirow[t]{2}{*}{ Variables } & \multicolumn{4}{|l|}{ Clinical stage I/II } & \multicolumn{3}{|l|}{ Clinical stage III/IV } \\
\hline & Controls $(N=227)$ & Cancer $(\mathrm{N}=60)$ & ${ }^{*} \mathrm{OR}(95 \% \mathrm{Cl})$ & $P$ & Cancer $(\mathrm{N}=144)$ & AOR $(95 \% \mathrm{Cl})$ & $P$ \\
\hline \multicolumn{8}{|l|}{ rs2929973 } \\
\hline Co-dominant TT & $102(44.9)$ & $26(43.3)$ & $1.00^{\text {ref }}$ & & $74(51.4)$ & $1.00^{\text {ref }}$ & \\
\hline TG & $91(40.1)$ & $28(46.7)$ & $1.30(0.46-3.70)$ & 0.624 & 57 (39.6) & $0.88(0.54-1.42)$ & 0.591 \\
\hline GG & $34(15.0)$ & $6(10.0)$ & $1.71(0.60-4.85)$ & 0.315 & $13(9.0)$ & $0.58(0.28-1.21)$ & 0.144 \\
\hline Dominant TT & $102(44.9)$ & $26(43.3)$ & $1.00^{\mathrm{ref}}$ & & $74(51.4)$ & $1.00^{\text {ref }}$ & \\
\hline $\mathrm{TG}+\mathrm{GG}$ & $125(55.1)$ & $34(56.7)$ & $1.17(0.62-2.20)$ & 0.636 & $70(48.6)$ & $0.78(0.50-1.23)$ & 0.286 \\
\hline Recessive TT+TG & $193(85.0)$ & $54(90.0)$ & $1.00^{\text {ref }}$ & & $131(91.0)$ & $1.00^{\text {ref }}$ & \\
\hline GG & $34(15.0)$ & $6(10.0)$ & $0.67(0.25-1.81)$ & 0.433 & $13(9.0)$ & $0.61(0.30-1.23)$ & 0.163 \\
\hline \multicolumn{8}{|l|}{ rs7843546 } \\
\hline Co-dominant CC & $36(15.9)$ & $17(28.3)$ & $1.00^{\text {ref }}$ & & $24(16.7)$ & $1.00^{\text {ref }}$ & \\
\hline CT & $119(52.4)$ & $30(50.0)$ & $0.54(0.25-1.17)$ & 0.116 & $79(54.9)$ & $1.08(0.58-2.02)$ & 0.808 \\
\hline TT & $72(31.7)$ & $13(21.7)$ & $0.34(0.14-0.84)$ & $0.020^{*}$ & $41(28.5)$ & $0.90(0.46-1.77)$ & 0.756 \\
\hline Dominant CC & $36(15.9)$ & $17(28.3)$ & $1.00^{\text {ref }}$ & & $24(16.7)$ & $1.00^{\text {ref }}$ & \\
\hline $\mathrm{CT}+\mathrm{TT}$ & $191(84.1)$ & $43(71.7)$ & $0.46(0.22-0.96)$ & $0.038^{*}$ & $120(83.3)$ & $1.02(0.56-1.85)$ & 0.953 \\
\hline Recessive CT + CC & $155(68.3)$ & $47(78.3)$ & $1.00^{\text {ref }}$ & & $103(71.5)$ & $1.00^{\text {ref }}$ & \\
\hline $\mathrm{TT}$ & $72(31.7)$ & $13(21.7)$ & $0.52(0.25-1.10)$ & 0.087 & $41(28.5)$ & $0.87(0.54-1.41)$ & 0.569 \\
\hline \multicolumn{8}{|l|}{ rs10956697 } \\
\hline Co-dominant CC & $86(37.9)$ & $26(43.3)$ & $1.00^{\text {ref }}$ & & $69(47.9)$ & $1.00^{\text {ref }}$ & \\
\hline$A C$ & $114(50.2)$ & $27(45.0)$ & $0.84(0.43-1.63)$ & 0.609 & $61(42.4)$ & $0.72(0.45-1.16)$ & 0.176 \\
\hline AA & 27 (11.9) & $7(11.7)$ & $1.08(0.38-3.03)$ & 0.888 & $14(9.7)$ & $0.83(0.39-1.79)$ & 0.636 \\
\hline Dominant CC & $86(37.9)$ & $26(43.3)$ & $1.00^{\text {ref }}$ & & $69(47.9)$ & $1.00^{\text {ref }}$ & \\
\hline$A C+A A$ & $141(62.1)$ & $34(56.7)$ & $0.88(0.47-1.66)$ & 0.696 & $75(52.1)$ & $0.73(0.46-1.14)$ & 0.166 \\
\hline Recessive CC + AC & $200(88.1)$ & $53(88.3)$ & $1.00^{\text {ref }}$ & & $130(90.3)$ & $1.00^{\text {ref }}$ & \\
\hline AA & $27(11.9)$ & $7(11.7)$ & $1.18(0.45-3.13)$ & 0.739 & $14(9.7)$ & $0.97(0.47-2.01)$ & 0.943 \\
\hline
\end{tabular}

ref reference; AOR Adjusted odds ratio; 95\% Cl 95\% confidence interval; adjusted for age, BMI ethnicity, smoking and drinking alcohol

${ }^{*} P<0.05$ as statically significant

(rs7843546 and rs10956697) and gastric cancer susceptibility in various subgroups. More specifically, the SNP rs7843546 TT and CT + TT genotype reduced susceptibility to stage I/II gastric cancer, with $\mathrm{CC}$ as a reference. The presence of the rs7843546 $\mathrm{T}$ allele was also associated with a significantly reduced risk of gastric cancer in a Han population. In addition, we found that smokers and subjects $\geq 50$ years old carrying the $\mathrm{AC}$ or $\mathrm{AC}+\mathrm{AA}$ genotype of the WISP1 rs10956697 polymorphism were less likely than CC homozygotes to develop gastric cancer. Both SNPs were discovered, for the first time, to be associated with the gastric cancer.

Most previous researches on the association between WISP1 polymorphisms and cancer were focused on the SNPs rs2929970, rs2929973, and rs2977530. The SNPs rs2929970 and rs2929973 are located in the 3'UTR of the WISP1 gene, and rs2977530 is located in introns. In the first second, in 2010, Frank et al. investigated the association between the WISP1 SNP rs2929970 and colorectal cancer risk but found no evidence for the said risk [26]. Then, in 2015, Chen et al. found that the WISP1 SNPs rs16893344, rs2977530, rs2977537, and rs62514004 were related to susceptibility to lung cancer but found no significant association for the SNPs rs2929970 or rs2929973 [23]. By contrast, Lau et al. demonstrated that WISP1 SNP rs2929970 carriers with at least one G allele were susceptible to oral squamous cell carcinoma in 2017 [17]. Moreover, Chen et al. revealed that the WISP1 SNP rs2977530 (AG + GG) was associated with hepatocellular carcinoma development and that WISP1 SNPs rs62514004 (AG+GG) and rs16893344 (CT+ TT) were correlated with lower risks of large tumor size, reaching a later clinical stage of hepatocellular carcinoma, in 2018 [16]. Furthermore, Lin et al. demonstrated that the genotypes AG + GG in cases of WISP1 SNP rs2977530 reduced the susceptibility of Taiwanese women to invasive cervical cancer, whereas genotype AA in cases of rs2977537 increased said risk [19]. In addition, Lee et al. indicated that patients with urothelial cell carcinoma carrying rs2977530 genetic variants $(A G+G G)$ had a higher risk of developing a more invasive tumor stage and a large tumor [15]. Wang et al. found that breast cancer 
Table 4 Distribution frequency of WISP1 polymorphisms in controls and gastric cancer patients stratified by ethnicity

\begin{tabular}{|c|c|c|c|c|c|c|c|c|}
\hline \multirow[t]{2}{*}{ Variables } & \multicolumn{4}{|l|}{ Han } & \multicolumn{4}{|l|}{ Zhuang } \\
\hline & $\begin{array}{l}\text { Cancer } \\
(\mathrm{N}=99)\end{array}$ & $\begin{array}{l}\text { Controls } \\
(\mathrm{N}=112)\end{array}$ & OR $(95 \% \mathrm{Cl})$ & $P$ & $\begin{array}{l}\text { Cancer } \\
(\mathrm{N}=92)\end{array}$ & $\begin{array}{l}\text { Controls } \\
(\mathrm{N}=100)\end{array}$ & OR $(95 \% \mathrm{Cl})$ & $P$ \\
\hline \multicolumn{9}{|l|}{ rs2929973 } \\
\hline Co-dominant TT & 50 & 56 & $1.00^{\text {ref }}$ & & 45 & 40 & $1.00^{\text {ref }}$ & \\
\hline TG & 38 & 40 & $1.19(0.62-2.29)$ & 0.601 & 40 & 42 & $0.90(0.46-1.74)$ & 0.750 \\
\hline GG & 11 & 16 & $0.93(0.37-2.36)$ & 0.875 & 7 & 18 & $0.36(0.13-1.02)$ & 0.054 \\
\hline Dominant TT & 50 & 56 & $1.00^{\text {ref }}$ & & 45 & 40 & $1.00^{\text {ref }}$ & \\
\hline $\mathrm{TG}+\mathrm{GG}$ & 49 & 56 & $1.08(0.59-1.96)$ & 0.801 & 47 & 60 & $0.73(0.39-1.36)$ & 0.324 \\
\hline Recessive TT + TG & 88 & 96 & $1.00^{\text {ref }}$ & & 85 & 82 & $1.00^{\text {ref }}$ & \\
\hline GG & 11 & 16 & $0.85(0.35-2.06)$ & 0.714 & 7 & 18 & $0.38(0.14-1.02)$ & 0.055 \\
\hline \multicolumn{9}{|l|}{ rs7843546 } \\
\hline Co-dominant CC & 23 & 14 & $1.00^{\text {ref }}$ & & 15 & 17 & $1.00^{\text {ref }}$ & \\
\hline CT & 50 & 61 & $0.33(0.14-0.78)$ & $0.012^{*}$ & 52 & 51 & $1.53(0.64-3.64)$ & 0.335 \\
\hline $\mathrm{TT}$ & 26 & 37 & $0.29(0.11-0.76)$ & $0.012^{*}$ & 25 & 32 & $0.94(0.37-2.38)$ & 0.896 \\
\hline Dominant CC & 23 & 14 & $1.00^{\text {ref }}$ & & 15 & 17 & $1.00^{\text {ref }}$ & \\
\hline $\mathrm{CT}+\mathrm{TT}$ & 76 & 98 & $0.32(0.14-0.74)$ & $0.007^{*}$ & 77 & 83 & $1.27(0.56-2.87)$ & 0.570 \\
\hline Recessive $\mathrm{CT}+\mathrm{CC}$ & 73 & 75 & $1.00^{\text {ref }}$ & & 67 & 68 & $1.00^{\text {ref }}$ & \\
\hline TT & 26 & 37 & $0.73(0.37-1.41)$ & 0.348 & 25 & 32 & $0.69(0.35-1.36)$ & 0.285 \\
\hline \multicolumn{9}{|l|}{ rs10956697 } \\
\hline Co-dominant CC & 48 & 41 & $1.00^{\text {ref }}$ & & 41 & 36 & $1.00^{\text {ref }}$ & \\
\hline$A C$ & 38 & 58 & $0.71(0.37-1.36)$ & 0.308 & 44 & 50 & $0.82(0.43-1.56)$ & 0.542 \\
\hline AA & 13 & 13 & $1.23(0.47-3.23)$ & 0.678 & 7 & 14 & $0.52(0.18-1.56)$ & 0.246 \\
\hline Dominant CC & 48 & 41 & $1.00^{\text {ref }}$ & & 41 & 36 & $1.00^{\text {ref }}$ & \\
\hline$A C+A A$ & 51 & 71 & $0.78(0.42-1.42)$ & 0.412 & 51 & 64 & $0.76(0.41-1.42)$ & 0.385 \\
\hline Recessive $C C+A C$ & 86 & 99 & $1.00^{\mathrm{ref}}$ & & 85 & 86 & $1.00^{\text {ref }}$ & \\
\hline$A A$ & 13 & 13 & $1.42(0.57-3.51)$ & 0.449 & 7 & 14 & $0.59(0.21-1.65)$ & 0.310 \\
\hline
\end{tabular}

ref reference; AOR Adjusted odds ratio; $95 \%$ Cl 95\% confidence interval; adjusted for gender, age, BMI smoking and drinking alcohol; * $P<0.05$ as statically significant

patients with the WISP1 rs2929973 GG + TT genotype were likely to develop estrogen receptor (ER)- and progesterone receptor (PR)-positive tumor status [14]. Our study does not support the hypothesis that WISP1 polymorphisms contribute to gastric cancer risk. However, our results provide evidence that gastric cancer subsets may be affected. Our results parallel the previous results reported by Lee [15], Chen [16], and Frank [26] but are not in accord with the results reported by Lau [17], Lin [19], and Wang [14]. These results demonstrate the variety of WISP1 polymorphisms in various cancers. There are two potential reasons for these inconsistencies that we may consider. One is that WISP1 expression varies in different cancers. Recent research has revealed that the roles of WISP1 in cancer occurrence and progression are diverse in different kinds of cancer. For example, WISP1 was found to negatively regulate the progress of cell motility and invasion via the inhibition of Rac function through integrins in lung cancer [27]. In contrast, WISP-1 was up-regulated in gastric cancer tissues as compared with their adjacent noncancerous tissues, suggesting that WISP-1 acts as an oncogene in gastric cancer. Similar results were found in previous studies of liver cancer [28], breast cancer [29], and endometrial adenocarcinoma [30]. The other potential reason is that the various ethnicities of the patients included in the aforementioned studies. Frank [26] studied Caucasians, but Wang [14], Lin [19], Lee [15], Lau [17], and Chen [16, $18,23]$ studied Asians. Our samples are taken from South Chinese population that is East Asian. In particular, our results revealed that the SNP rs7843546 TT genotype was associated with a significantly reduced risk of gastric cancer in a Han population but not a Zhuang population. This further indicated that WISP1 genotype distributions are different in different ethnicities.

Helicobacter pylori infection, aging, gender, smoking, and alcohol consumption are the main risk factor for the development of gastric cancer [31]. In order to rule out the influence of a confounding factor, $H$. pylori infection, we did not include $H$. pylori infection patients in our study. We further analyzed the correlations of WISP1 SNP polymorphisms with other confounding factors for 
Table 5 Distribution frequency of WISP1 polymorphisms in controls and gastric cancer patients stratified by cell differentiation

\begin{tabular}{|c|c|c|c|c|c|c|c|}
\hline \multirow[t]{2}{*}{ Variables } & \multicolumn{4}{|c|}{ Moderate and poor differentiation } & \multicolumn{3}{|c|}{ Well differentiation } \\
\hline & Controls $(\mathrm{N}=227)$ & Cancer $(\mathrm{N}=168)$ & AOR $(95 \% \mathrm{Cl})$ & $P$ & Cancer $(\mathrm{N}=36)$ & AOR $(95 \% \mathrm{Cl})$ & $P$ \\
\hline \multicolumn{8}{|l|}{ rs2929973 } \\
\hline Co-dominant TT & 102(44.9) & $81(48.2)$ & $1.00^{\mathrm{ref}}$ & & 19(52.8) & $1.00^{\text {ref }}$ & \\
\hline TG & $91(40.1)$ & $72(42.9)$ & $1.03(0.65-1.62)$ & 0.912 & 13(36.1) & $0.86(0.36-2.07)$ & 0.730 \\
\hline GG & $34(15.0)$ & $15(8.9)$ & $0.60(0.29-1.21)$ & 0.151 & $4(11.1)$ & $0.96(0.27-3.39)$ & 0.953 \\
\hline Dominant TT & $102(44.9)$ & $81(48.2)$ & $1.00^{\mathrm{ref}}$ & & 19(52.8) & $1.00^{\text {ref }}$ & \\
\hline $\mathrm{TG}+\mathrm{GG}$ & $125(55.1)$ & $87(51.8)$ & $0.90(0.58-1.37)$ & 0.612 & $17(47.2)$ & $0.88(0.39-1.99)$ & 0.766 \\
\hline Recessive TT + TG & 193(85.0) & 153(91.1) & $1.00^{\text {ref }}$ & & $32(88.9)$ & $1.00^{\text {ref }}$ & \\
\hline GG & $34(15.0)$ & $15(8.9)$ & $0.59(0.30-1.14)$ & 0.117 & $4(11.1)$ & $1.03(0.31-3.42)$ & 0.960 \\
\hline \multicolumn{8}{|l|}{ rs7843546 } \\
\hline Co-dominant CC & $36(15.9)$ & $34(20.2)$ & $1.00^{\mathrm{ref}}$ & & $7(19.4)$ & $1.00^{\text {ref }}$ & \\
\hline $\mathrm{CT}$ & 119(52.4) & $86(51.2)$ & $0.79(0.45-1.41)$ & 0.426 & 23(63.9) & $1.14(0.40-3.24)$ & 0.801 \\
\hline TT & $72(31.7)$ & $48(28.6)$ & $0.71(0.38-1.31)$ & 0.272 & $6(16.7)$ & $0.42(0.11-1.56)$ & 0.197 \\
\hline Dominant CC & $36(15.9)$ & $34(20.2)$ & $1.00^{\mathrm{ref}}$ & & $7(19.4)$ & $1.00^{\text {ref }}$ & \\
\hline $\mathrm{CT}+\mathrm{TT}$ & $191(84.1)$ & 134(79.8) & $0.77(0.45-1.32)$ & 0.333 & 29(80.6) & $0.87(0.31-2.39)$ & 0.782 \\
\hline Recessive CT + CC & 155(68.3) & 120(71.4) & $1.00^{\text {ref }}$ & & $30(83.3)$ & $1.00^{\text {ref }}$ & \\
\hline TT & 72(31.7) & $48(28.6)$ & $0.86(0.54-1.35)$ & 0.504 & $6(16.7)$ & $0.38(0.14-1.07)$ & 0.067 \\
\hline \multicolumn{8}{|l|}{ rs10956697 } \\
\hline Co-dominant CC & $86(37.9)$ & $79(47.0)$ & $1.00^{\mathrm{ref}}$ & & $16(44.4)$ & $1.00^{\text {ref }}$ & \\
\hline$A C$ & $114(50.2)$ & $70(41.7)$ & $0.73(0.46-1.14)$ & 0.165 & $18(50.0)$ & $0.90(0.39-2.04)$ & 0.792 \\
\hline$A A$ & $27(11.9)$ & 19(11.3) & $0.96(0.47-1.93)$ & 0.902 & $2(5.6)$ & $0.67(0.13-3.55)$ & 0.636 \\
\hline Dominant CC & $86(37.9)$ & $79(47.0)$ & $1.00^{\text {ref }}$ & & $16(44.4)$ & $1.00^{\text {ref }}$ & \\
\hline$A C+A A$ & $141(62.1)$ & $89(53.0)$ & $0.76(0.49-1.16)$ & 0.201 & 20(55.6) & $0.86(0.39-1.93)$ & 0.719 \\
\hline Recessive CC + AC & $200(88.1)$ & 149(88.7) & $1.00^{\mathrm{ref}}$ & & $34(94.4)$ & $1.00^{\text {ref }}$ & \\
\hline AA & $27(11.9)$ & $19(11.3)$ & $1.12(0.58-2.17)$ & 0.739 & $2(5.6)$ & $0.71(0.14-3.55)$ & 0.677 \\
\hline
\end{tabular}

ref reference; AOR Adjusted odds ratio; 95\% Cl 95\% confidence interval; adjusted for gender, age, BMI, ethnicity, smoking and drinking alcohol

gastric cancer patients. After stratifying individuals into smokers and nonsmokers, smokers with the AC genotype in WISP1 SNP rs10956697 displayed a 0.28-fold lower risk (95\% CI 0.09-0.82) of gastric cancer. Smoking is a well-known carcinogen, including for gastric cancer, and nicotine exposure is suggested to promote cancer progression by activating the Wnt/ $\beta$-catenin and Wnt/ PCP signaling pathways [32]. Aging is also a significant risk factor for gastric cancer. We stratified our included subjects according to a person's age. We found that subjects $\geq 50$ years old carrying the WISP1 rs10956697 AC genotype were at a 0.58 -fold (95\% CI $0.35-0.98$ ) lower risk than CC homozygotes of developing gastric cancer. Aging is the process of the degeneration of the body, from constitutive substances and tissue structures to physiological functions [33]. The time-dependent accumulation of cellular damage is widely considered to be the general cause of aging [34]. Concomitantly, cellular damage may occasionally provide aberrant advantages to certain cells, which can eventually produce cancer [33].

The current findings must be interpreted in light of several potential limitations. Firstly, we did not obtain positive results in overall cases, but we did obtain some positive results in the subgroup analysis. The evidence for different effects on the part of aging, smoking, and ethnicity on gastric cancer risk was suggestive but not conclusive. The sample size for the study was not large enough, and the sample size in each subgroup was too small; thus, the results lack statistical power and robustness. A larger independent-cohort study is required to confirm the result we obtained. Secondly, the study was limited to eligible participations in Guangxi (Southwest China), which may not be representative of the entire Chinese population. Therefore, these findings may not be generalized to other populations. Thirdly, this research was based on data from individual participants, and only three SNPs of the WISP1 gene were selected, which restricted interpretations regarding gene-to-gene interactions. These limitations restrict the interpretation and extrapolation of the current findings. The evidence for different effects on the part of age, smoking, ethnic group, and cancer stage on gastric cancer risk is suggestive but not conclusive. The mechanisms underlying these differences are also still unknown. One potential 
explanation may be the limited study numbers. After we stratified our population by age, smoking status, ethnic group, and cancer stage, the sample size grew smaller in each subgroup. Thus, the results lack statistical power and robustness. It would be interesting to identify more validation cohorts from other regions and more SNPs in the WISP1 gene and thus investigate their associations with gastric cancer risk.

\section{Conclusions}

Overall, we could not identify a significant association between WISP1 SNPs rs2929973, rs7843546, and rs10956697 and gastric cancer risk. However, our results suggest that a subset of subjects may be affected, including patients with $\geq 50$ years old carrying the AC genotype of rs10956697, smoking patients carrying the AC or AC + AA genotype of rs10956697, Han people carrying the CT or TT genotype of rs7843546, and stage I/II gastric patients carrying $\mathrm{TT}$ and $\mathrm{CT}+\mathrm{TT}$ genotype of rs7843546. All these polymorphisms were, for the first time, discovered to represent a significantly reduced risk of gastric cancer. Replication in further epidemiologic studies and functional analyses is warranted to confirm these findings.

\section{Abbreviations}

BMI: Body mass index; Cl: Confidence interval; OR: Odds ratio; PCR-RFLP: Polymerase chain reaction-restriction fragment length polymorphism; SNP: Single-nucleotide polymorphism; WISP1: WNT1-inducible signaling pathway protein-1.

\section{Supplementary Information}

The online version contains supplementary material available at https://doi. org/10.1186/s12935-021-02116-2.

Additional file 1. Distribution frequency of WISP1 polymorphisms in controls and gastric cancer patients stratified by age.

Additional file 2. Distribution frequency of WISP1 polymorphisms in controls and gastric cancer patients stratified by smoking status.

Additional file 3. Distribution frequency of WISP1 polymorphisms in controls and gastric cancer patients stratified by gender.

Additional file 4. Distribution frequency of WISP1 polymorphisms in controls and gastric cancer patients stratified by drinking status.

\section{Acknowledgements}

Not applicable.

\section{Authors' contributions}

YLiu performed the experiments and wrote the manuscript. WQ performed the experiments. FZ participated in the statistical analysis. JW and XL participated in the design of the study. YLu and XQ conceived of the study, and participated in its design and coordination and helped to draft the manuscript. All authors read and approved the final manuscript.

\section{Funding}

This study was supported by Self-financing Scientific Research Subject of Guangxi Health Department (Z20200085; Z20210158).
Availability of data and materials

The datasets supporting the conclusions of this article (are) included within the article and its additional files.

\section{Declarations}

Ethics approval and consent to participate

All procedures performed in studies involving human participants were in accordance with the ethical standards of the institutional and/or national research committee and with the 1964 Helsinki declaration and its later amendments or comparable ethical standards. Informed consent was obtained from all individual participants included in the study.

\section{Consent for publication}

This manuscript is approved by all authors for publication.

\section{Competing interests}

The authors declare that they have no conflict of interest.

\section{Author details}

${ }^{1}$ Department of Clinical Laboratory, The First Affiliated Hospital of Guangxi Medical University, Nanning, Guangxi, China. ${ }^{2}$ Department of Clinical Laboratory, The Second Affiliated Hospital of Guangxi Medical University, Nanning, Guangxi, China. ${ }^{3}$ Medical Equipment Department, The First Affiliated Hospital of Guangxi Medical University, Nanning, Guangxi, China.

Received: 19 April 2021 Accepted: 26 July 2021

Published online: 30 July 2021

\section{References}

1. Sung H, Ferlay J, Siegel RL. Global cancer statistics 2020: GLOBOCAN estimates of incidence and mortality worldwide for 36 cancers in 185 countries. CA Cancer J Clin. 2021. https://doi.org/10.3322/caac.21660.

2. International Agency for Research on Cancer. The global cancer observatory. Cancer today. http://gco.iarc.fr/. Accessed 8 Apr 2021.

3. Klingelhöfer D, Braun M, Schöffel N, Brüggmann D, Groneberg DA. Gastric cancer: bibliometric analysis of epidemiological, geographical and socio-economic parameters of the global research landscape. Int J Health Policy Manag. 2020. https://doi.org/10.34172/ijhpm.2020.29.

4. Plummer M, Franceschi S, Vignat J, Forman D, de Martel C. Global burden of gastric cancer attributable to Helicobacter pylori. Int J Cancer. 2015;136(2):487-90. https://doi.org/10.1002/ijc.28999.

5. Hooi JKY, Lai WY, Ng WK, Suen MMY, Underwood FE, Tanyingoh D, Malfertheiner P, Graham DY, Wong VWS, Wu JCY, et al. Global prevalence of Helicobacter pylori infection: systematic review and meta-analysis. Gastroenterology. 2017;153(2):420-9. https://doi.org/10.1053/j.gastro. 2017.04.022.

6. Kidd M, Lastovica AJ, Atherton JC, Louw JA. Heterogeneity in the Helicobacter pylori vacA and cagA genes: association with gastroduodenal disease in South Africa? Gut. 1999;45(4):499-502. https://doi.org/10.1136/ gut.45.4.499.

7. Maiese K.WISP1: clinical insights for a proliferative and restorative member of the CCN family. Curr Neurovasc Res. 2014;11(4):378-89. https://doi. org/10.2174/1567202611666140912115107.

8. Berwick DC, Harvey K. The regulation and deregulation of Wnt signaling by PARK genes in health and disease. J Mol Cell Biol. 2014;6(1):3-12. https://doi.org/10.1093/jmcb/mjt037.

9. Gurbuz I, Chiquet-Ehrismann R. CCN4/WISP1 (WNT1 inducible signaling pathway protein 1): a focus on its role in cancer. Int J Biochem Cell Biol. 2015;62:142-6. https://doi.org/10.1016/j.biocel.2015.03.007.

10. Jia S, Qu T, Feng M, Ji K, Li Z, Jiang W, Ji J. Association of Wnt1-inducible signaling pathway protein-1 with the proliferation, migration and invasion in gastric cancer cells. Tumour Biol. 2017;39(6):1010428317699755. https://doi.org/10.1177/1010428317699755.

11. Zhang LH, Wang Y, Fan QQ, Liu YK, Li LH, Qi XW, Mao Y, Hua D. Up-regulated Wnt1-inducible signaling pathway protein 1 correlates with poor prognosis and drug resistance by reducing DNA repair in gastric cancer. 
World J Gastroenterol. 2019;25(38):5814-25. https://doi.org/10.3748/wjg. V25.138.5814.

12. Shastry BS. SNPs: impact on gene function and phenotype. Methods Mol Biol. 2009;578:3-22. https://doi.org/10.1007/978-1-60327-411-1_1.

13. Davies SR, Watkins G, Mansel RE, Jiang WG. Differential expression and prognostic implications of the CCN family members WISP-1, WISP-2, and WISP-3 in human breast cancer. Ann Surg Oncol. 2007;14(6):1909-18. https://doi.org/10.1245/s10434-007-9376-X.

14. Wang Y, Yang SH, Hsu PW, Chien SY, Wang CQ, Su CM, Dong XF, Zhao YM, Tang CH. Impact of WNT1-inducible signaling pathway protein-1 (WISP-1) genetic polymorphisms and clinical aspects of breast cancer. Medicine (Baltimore). 2019;98(44): e17854. https://doi.org/10.1097/md.0000000000 017854.

15. Lee HL, Chiou HL, Wang SS, Hung SC, Chou MC, Yang SF, Hsieh MJ, Chou YE. WISP1 genetic variants as predictors of tumor development with urothelial cell carcinoma. Urol Oncol. 2018;36(4):160.e115-160.e121. https://doi.org/10.1016/j.urolonc.2017.11.023.

16. Chen CT, Lee HL, Chiou HL, Chou CH, Wang PH, Yang SF. Impacts of WNT1-inducible signaling pathway protein 1 polymorphism on hepatocellular carcinoma development. PLoS ONE. 2018:13(6): e0198967. https://doi.org/10.1371/journal.pone.0198967.

17. Lau HK, Wu ER, Chen MK, Hsieh MJ, Yang SF, Wang LY, Chou YE. Effect of genetic variation in microRNA binding site in WNT1-inducible signaling pathway protein 1 gene on oral squamous cell carcinoma susceptibility. PLoS ONE. 2017;12(4): e0176246. https://doi.org/10.1371/journal.pone. 0176246.

18. Chen J, Yin J, Li X, Wang Y, Zheng Y, Qian C, Xiao L, Zou T, Wang Z, Liu J, et al. WISP1 polymorphisms contribute to platinum-based chemotherapy toxicity in lung cancer patients. Int J Mol Sci. 2014;15(11):21011-27. https://doi.org/10.3390/ijms151121011.

19. Lin YH, Hsiao YH, Yang SF, Liu YF, Hsu CF, Wang PH. Association between genetic polymorphisms of WNT1 inducible signaling pathway protein 1 and uterine cervical cancer. Reprod Sci. 2018;25(11):1549-56. https://doi. org/10.1177/1933719118756749.

20. Gauderman WJ. Sample size requirements for matched case-control studies of gene-environment interaction. Stat Med. 2002;21 (1):35-50. https://doi.org/10.1002/sim.973.

21. Gauderman WJ. Sample size requirements for association studies of gene-gene interaction. Am J Epidemiol. 2002;155(5):478-84. https://doi. org/10.1093/aje/155.5.478.

22. LiT, Qin W, Liu Y, Li S, Qin X, Liu Z. Effect of RAGE gene polymorphisms and circulating sRAGE levels on susceptibility to gastric cancer: a case-control study. Cancer Cell Int. 2017;17:19. https://doi.org/10.1186/ s12935-017-0391-0.

23. Chen J, Yin JY, Li XP, Wang Y, Zheng Y, Qian CY, He H, Fang C, Wang Z, Zhang $Y$ et al. Association of Wnt-inducible signaling pathway protein 1 genetic polymorphisms with lung cancer susceptibility and platinumbased chemotherapy response. Clin Lung Cancer 2015, 16(4):298-304. e291-292.doi:https://doi.org/10.1016/j.cllc.2014.12.008.
24. Liu Y, Xie L, Zhao J, Huang X, Song L, Luo J, Ma L, Li S, Qin X. Association between catalase gene polymorphisms and risk of chronic hepatitis B, hepatitis B virus-related liver cirrhosis and hepatocellular carcinoma in Guangxi population: a case-control study. Medicine (Baltimore). 2015;94(13): e702. https://doi.org/10.1097/md.0000000000000702.

25. Nagai Y, Watanabe M, Ishikawa S, Karashima R, Kurashige J, Iwagami S, Iwatsuki M, Baba Y, Imamura Y, Hayashi N, et al. Clinical significance of Wnt-induced secreted protein-1 (WISP-1/CCN4) in esophageal squamous cell carcinoma. Anticancer Res. 2011;31(3):991-7.

26. Frank B, Hoffmeister M, Klopp N, Illig T, Chang-Claude J, Brenner H. Single nucleotide polymorphisms in Wnt signaling and cell death pathway genes and susceptibility to colorectal cancer. Carcinogenesis. 2010;31(8):1381-6. https://doi.org/10.1093/carcin/bgq082.

27. Su F, Overholtzer M, Besser D, Levine AJ. WISP-1 attenuates p53-mediated apoptosis in response to DNA damage through activation of the Akt kinase. Genes Dev. 2002;16(1):46-57. https://doi.org/10.1101/gad.942902.

28. Calvisi DF, Conner EA, Ladu S, Lemmer ER, Factor VM, Thorgeirsson SS. Activation of the canonical Wnt/beta-catenin pathway confers growth advantages in C-Myc/E2F1 transgenic mouse model of liver cancer. J Hepatol. 2005:42(6):842-9. https://doi.org/10.1016/j.jhep.2005.01.029.

29. Chiang KC, Yeh CN, Chung LC, Feng TH, Sun CC, Chen MF, Jan YY, Yeh TS, Chen SC, Juang HH. WNT-1 inducible signaling pathway protein-1 enhances growth and tumorigenesis in human breast cancer. Sci Rep. 2015;5:8686. https://doi.org/10.1038/srep08686.

30. Tang Q, Jiang X, Li H, Lin Z, Zhou X, Luo X, Liu L, Chen G. Expression and prognostic value of WISP-1 in patients with endometrial endometrioid adenocarcinoma. J Obstet Gynaecol Res. 2011;37(6):606-12. https://doi, org/10.1111/j.1447-0756.2011.01631.x

31. Machlowska J, Baj J, Sitarz M, Maciejewski R, Sitarz R. Gastric cancer: epidemiology, risk factors, classification, genomic characteristics and treatment strategies. Int J Mol Sci. 2020;21(11):4012. https://doi.org/10. 3390/ijms21114012.

32. Chung TT, Pan MS, Kuo CL, Wong RH, Lin CW, Chen MK, Yang SF. Impact of RECK gene polymorphisms and environmental factors on oral cancer susceptibility and clinicopathologic characteristics in Taiwan. Carcinogenesis. 2011;32(7):1063-8. https://doi.org/10.1093/carcin/bgr083.

33. López-Otín C, Blasco MA, Partridge L, Serrano M, Kroemer G. The hallmarks of aging. Cell. 2013;153(6):1194-217. https://doi.org/10.1016/j.cell. 2013.05.039.

34. Vijg J, Campisi J. Puzzles, promises and a cure for ageing. Nature. 2008:454(7208):1065-71. https://doi.org/10.1038/nature07216.

\section{Publisher's Note}

Springer Nature remains neutral with regard to jurisdictional claims in published maps and institutional affiliations.
Ready to submit your research? Choose BMC and benefit from:

- fast, convenient online submission

- thorough peer review by experienced researchers in your field

- rapid publication on acceptance

- support for research data, including large and complex data types

- gold Open Access which fosters wider collaboration and increased citations

- maximum visibility for your research: over 100M website views per year

At BMC, research is always in progress.

Learn more biomedcentral.com/submissions 